\title{
RETAINED SURGICAL SWAB DEBRIS IN POST-LAMINECTOMY ARACHNOIDITIS AND PERIDURAL FIBROSIS
}

\author{
JUDITH A. HOYLAND, A. J. FREEMONT, J. DENTON, A. M. C. THOMAS, J. J. McMILLAN, M. I. V. JAYSON \\ From Queen Elizabeth Hospital and the Royal Orthopaedic Hospital, Birmingham and the University of \\ Manchester
}

We examined soft tissue biopsies from 26 patients with symptomatic nerve root fibrosis and arachnoiditis after a previous laminectomy. Dense fibrous connective tissue was found about the nerve roots and in 14 cases $\mathbf{( 5 5 \% )}$ ) fibrillar foreign material was seen within it. This material had the histochemical characteristics of cotton fibres from swabs and neurosurgical patties. In two other cases nerve root fibrosis was associated with residual radiopaque lipid thought to derive from earlier myelography.

Our findings suggest that risks may be associated with the introduction of foreign material into the vertebral canal, and that microscopic fragments of surgical swabs and patties may have a role in the pathogenesis of postoperative periradicular fibrosis.

Spinal arachnoiditis and periradicular "inflammation" of the arachnoid membrane and adjacent peridural structures lead to fibrosis within and around the lumbar dural sac and the spinal nerve roots (Burton 1983). Arachnoiditis may result from exogenous factors such as infection (Freilick and Swash 1979) or the use of spinal anaesthetics (Reisner, Hochman and Plumer 1980). Peridural fibrosis also occurs in association with degenerative lumbar disc disease (Ransford and Harries 1972) and canal stenosis (Clark 1969) but is much more common as a secondary result of the use of oil-based myelographic contrast media (Jakobsen 1973), or of spinal surgery (Benoist et al. 1980).

Most patients who have a surgical decompression for disc protrusion or bony entrapment obtain good long term relief of radicular pain. A minority, after initial improvement, have recurrence of pain. When recurrent disc protrusion and unrecognised root entrapment have been excluded, arachnoiditis and peridural fibrosis are the most important causes of recrudescence of pain after disc surgery. The only effective treatment for peridural scarring is further operative excision; this produces a

J. A. Hoyland, BSc, Research Assistant

A. J. Freemont, MD, MRCPath, Lecturer in Osteoarticular Pathology J. Denton, Chief Technician

M. I. V. Jayson, MD, FRCP, Professor of Rheumatology

Department of Rheumatology, Stopford Building, University of Manchester, Oxford Road, Manchester M13 9PT, England.

A. M. C. Thomas, FRCS, Registrar in Orthopaedic Surgery

The Royal Orthopaedic Hospital, Woodlands, Northfield, Birmingham B31 2AP, England.

J. J. McMillan, FRCS, Consultant Neurosurgeon

The Queen Elizabeth Hospital, Queen Elizabeth Medical Centre, Edgbaston, Birmingham B13 2TH, England.

Correspondence should be sent to Miss J. A. Hoyland.

(C) 1988 British Editorial Society of Bone and Joint Surgery

0301-620X/88/4102 $\$ 2.00$

J Bone Joint Surg [Br] 1988;70-B :659-62. satisfactory improvement in a proportion of cases. Relapse is common and although the incidence may be reduced by peridural fat grafting (Van Akkeveeken, Van De Kraan and Muller 1986) it remains a cause of serious morbidity.

To elucidate the pathogenesis of such relapse, we have examined the histology of perineural fibrotic tissue removed from 26 patients at a repeated spinal operation.

\section{PATIENTS}

Patients had been referred to the neurosurgical department of the Queen Elizabeth Hospital for treatment of intractable root pain after previous lumbar disc surgery. All had radiculography using a water-soluble contrast medium (Niopam) with a CT examination when this was indicated. When significant compression of the dural sac or root sleeves was identified, surgical exploration was advised.

Patients with recurrence of disc protrusion or bony entrapment were excluded from our study, leaving 26 patients (Table I) who had significant peridural scarring. Biopsies of the scar tissue were obtained in all cases. In six cases the dura was opened to allow decompression of the enclosed structures but no detailed intrathecal dissection of nerve roots was performed.

\section{METHODS}

Specimens were fixed in formalin and embedded in paraffin wax and $5 \mu \mathrm{m}$ sections were stained with haematoxylin and eosin, Miller's elastic stain, Masson's trichrome, and Martius scarlet blue stain. These sections were examined by conventional and polarising microscopy. Samples of various neurosurgical patties, of larger surgical swabs and of filter paper (as cellulose control 
specimens) were processed in a similar manner to obtain minute specimens of both types of material.

Sections of the biopsy material and the samples were also stained with periodic acid schiff (PAS), Congo red and Grocotts Gomori - all specific stains for cellulose. Sections were also treated with Schweizer's reagent and iodine-sulphuric acid to provide specific reactions for the identification of cellulose (Gatenby and Beams 1950), the reactions being followed under the microscope. Other sections were also treated with a $1 \%$ solution of cellulase $(1,4[1,3,1,4]-\mathrm{B}-\mathrm{D}$ glucan 4 glucanohydrolase, at pH 5 and $37^{\circ} \mathrm{C}$ for one hour before they were stained for cellulose.

\section{RESULTS}

In all cases the soft tissue about the nerve root was found to have been replaced by fibrous tissue with large amounts of well-organised mature collagen. In many cases this tissue contained both well-formed blood vessels and occasionally vascular channels of the character of proliferating capillaries. Rarely, these were associated with a perivascular lymphocytic infiltrate and in three biopsies intravascular and extravascular fibrin deposition was seen. Some biopsies included adipose tissue at the periphery of the areas of fibrosis, and at this interface the fibrous septae between fat lobules were seen to be thickened by excess deposition of collagen.

In 16 of the biopsies, some foreign material was seen; this was of two types. Oil granulomata were seen in two patients, a 28-year-old woman and a 35-year-old man both of whom had had a previous oil-based myelogram. These granulomata consisted of aggregated lipid droplets which had induced a foreign-body giant cell reaction within the dense fibrous tissue. Microradiography of unstained frozen sections confirmed that the spaces contained radiopaque material.

Fibrillar, refractile birefringent particles were found within the fibrous tissue in 14 biopsies (Fig. 1). Where this foreign material had been cut transversely it had the structure of a hollow flat tube (Figs $2 a$ and $2 b$ ). In most cases there was a macrophage response and much of the material had been phagocytosed by mono- and multi-nucleated phagocytes (Figs $3 a$ and $3 b$ ). Such a response confirmed that the material had been present in the tissues for some time before the biopsy was taken.

We felt that this foreign material had probably been introduced at the time of previous surgery, so we compared it with fibres that might possibly have entered the operation site. The appearance of a flattened tube is characteristic of cotton fibres, so we undertook a comparative histochemical analysis of the biopsied fibres and of cotton fibres from patties and swabs (Table II). This analysis showed the biopsy material to be based on cellulose, which had identical histochemical and structural characteristics to those of the swab and pattie samples. Both the debris and fragmented swab or pattie

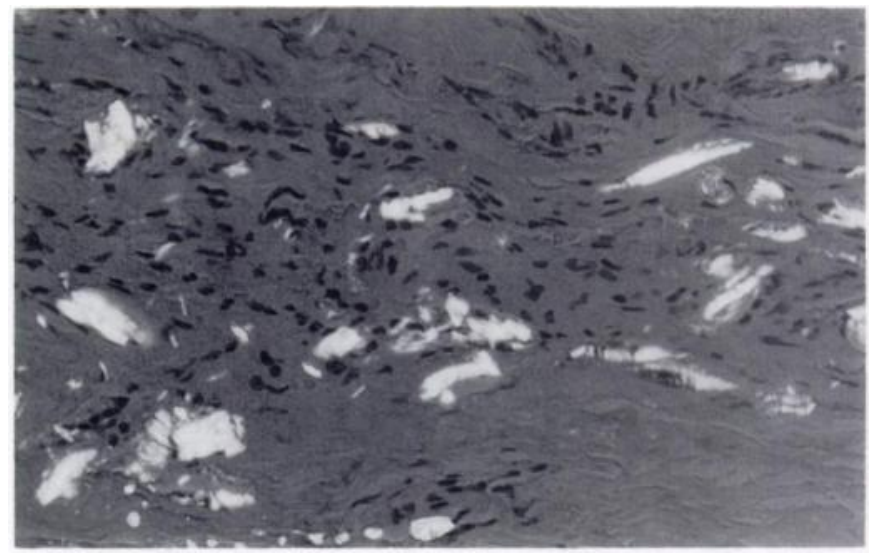

Fig. 1

Case 10. Peridural tissue viewed with polarising microscopy showing fragments of fibrillar, birefringent foreign material within fibrous tissue and in close association with chronic inflammatory cells (haematoxylin and eosin $\times 380$ ).

Table I. Clinical details of the 26 patients

\begin{tabular}{|c|c|c|c|c|c|}
\hline $\begin{array}{l}\text { Case } \\
\text { number }\end{array}$ & $\begin{array}{l}\text { Age } \\
\text { in } \\
\text { years }\end{array}$ & Sex & $\begin{array}{l}\text { Number of } \\
\text { previous } \\
\text { operations }\end{array}$ & $\begin{array}{l}\text { Date of } \\
\text { first } \\
\text { operation }\end{array}$ & $\begin{array}{l}\text { Date of } \\
\text { biopsy }\end{array}$ \\
\hline 1 & 64 & $\mathbf{M}$ & 2 & 1978 & Mar 1985 \\
\hline 2 & 28 & $\mathrm{~F}$ & 1 & 1981 & Aug 1985 \\
\hline 3 & 72 & $\mathbf{M}$ & 2 & 1976 & Nov 1985 \\
\hline 4 & 35 & $\mathbf{M}$ & 2 & 1983 & July 1986 \\
\hline 5 & 57 & $\mathbf{M}$ & 1 & 1968 & Aug 1986 \\
\hline 6 & 38 & $\mathbf{M}$ & 1 & 1984 & Oct 1986 \\
\hline 7 & 39 & $F$ & 1 & 1984 & Mar 1985 \\
\hline 8 & 74 & $\mathbf{M}$ & 2 & 1975 & May 1985 \\
\hline 9 & 37 & $\mathrm{~F}$ & 1 & 1985 & Jan 1986 \\
\hline 10 & 39 & $F$ & 2 & 1982 & Feb 1986 \\
\hline 11 & 42 & $F$ & 3 & 1984 & July 1986 \\
\hline 12 & 53 & $F$ & 1 & 1985 & July 1986 \\
\hline 13 & 55 & $\mathbf{F}$ & 1 & 1982 & Oct 1986 \\
\hline 14 & 26 & $\mathbf{F}$ & 2 & 1980 & Mar 1985 \\
\hline 15 & 56 & $\mathbf{F}$ & 1 & 1982 & Aug 1985 \\
\hline 16 & 25 & $\mathbf{F}$ & 1 & 1985 & July 1986 \\
\hline 17 & 33 & $\mathbf{M}$ & 1 & 1976 & Aug 1986 \\
\hline 18 & 59 & $\mathbf{M}$ & 1 & 1985 & May 1986 \\
\hline 19 & 23 & $\mathbf{M}$ & 1 & 1983 & Aug 1986 \\
\hline 20 & 39 & $\mathbf{M}$ & 2 & 1984 & May 1985 \\
\hline 21 & 35 & $\mathbf{M}$ & 1 & 1985 & July 1985 \\
\hline 22 & 44 & $F$ & 1 & 1980 & Feb 1986 \\
\hline 23 & 69 & $\mathbf{M}$ & 2 & 1975 & July 1986 \\
\hline 24 & 35 & $F$ & 1 & 1985 & Aug 1986 \\
\hline 25 & 46 & $\mathbf{M}$ & 1 & 1970 & Aug 1986 \\
\hline 26 & 58 & $\mathbf{F}$ & 1 & 1984 & Sep 1986 \\
\hline
\end{tabular}


material were composed of cellulose that had been chemically altered, for example by cross-linking or resin coating, presumably as a result of the manufacturing process.

\section{DISCUSSION}

Arachnoiditis and peridural fibrosis are serious complications of spinal surgery, as they may lead to intractable nerve root pain which is difficult to control. Excision of scar tissue is the only effective treatment but recurrence of pain will follow in a significant number of patients. In all of our 26 patients it seemed that active arachnoiditis and peridural fibrosis were continuing.

As elsewhere, surgical trauma about the epidural space causes the production of granulation tissue and then the deposition of collagen by infiltrating fibroblasts. This is often self-limiting, but in certain individuals excessive fibrous tissue may accumulate - as in skin keloid and abdominal adhesions. It is these patients who develop significant peridural fibrosis with intractable debilitating pain. Many factors may be involved in this

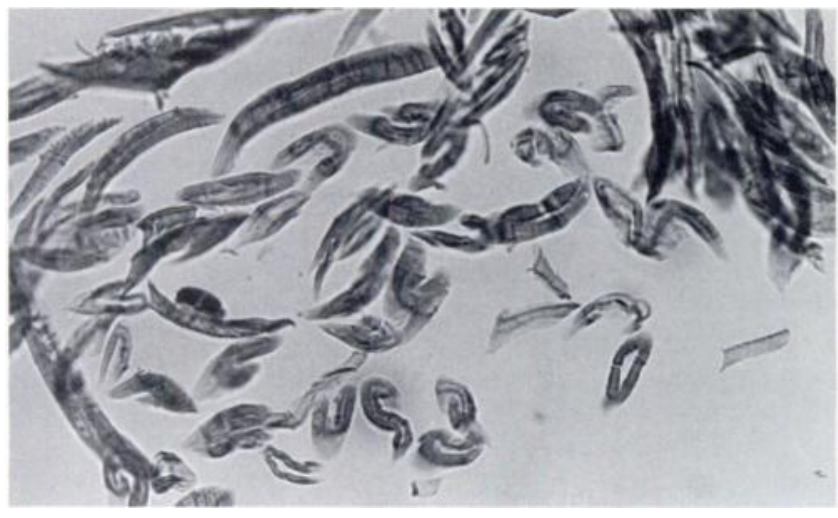

Fig. 2a process, including the presence of blood, haemostatic agents, or infection. The opening of the dura has also been suggested as contributing to the development of arachnoiditis.

In 14 of our 26 cases we found fibrillar foreign material in association with active macrophages and less commonly with other chronic inflammatory cells. Foreign material can stimulate granulomatous and other chronic inflammatory reactions, which outside the vertebral column are associated with fibrosis and scar formation (Seaton 1975). Although activated macrophages have been shown to produce both collagenases (Werb, Bainton and Jones 1980) and factors which stimulate the proliferation and activity of fibroblasts in vitro (Wahl 1984), it is suggested that in vivo $\alpha_{2}$ macroglobulin and $\beta_{1}$ anti-collagenase (both present in injured tissue) would inhibit collagen breakdown (Deporter 1979). Thus the activation of macrophages associated with the phagocytosis of foreign material could lead to the production of fibroblast-stimulating factors and consequently to fibrosis.

Persistence of this material would lead to continu-

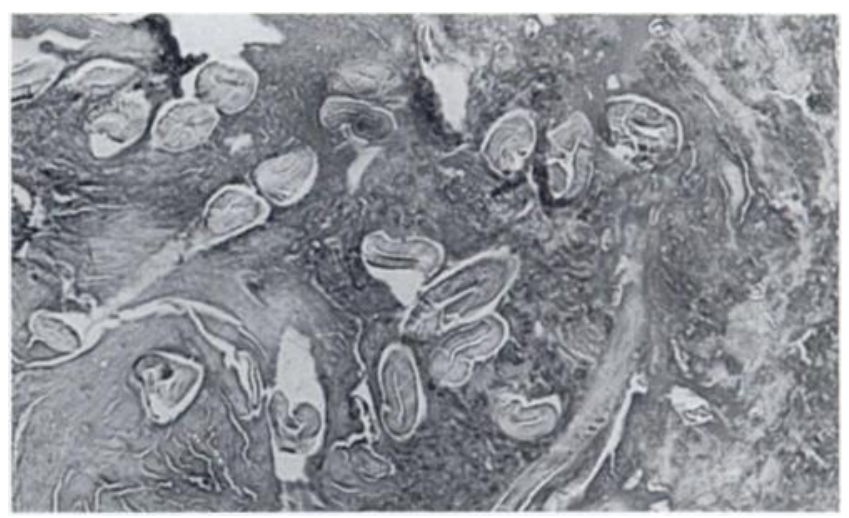

Fig. $2 b$

Figure $2 \mathrm{a}$ - Section of surgical swab material showing a characteristic flattened tube-like appearance. Figure $2 \mathrm{~b}-\mathrm{Case} 11$. Perineural biopsy of fibrous tissue containing foreign material which has the same flattened tube appearance as the swab (Grocotts Gomori $x$ 90).

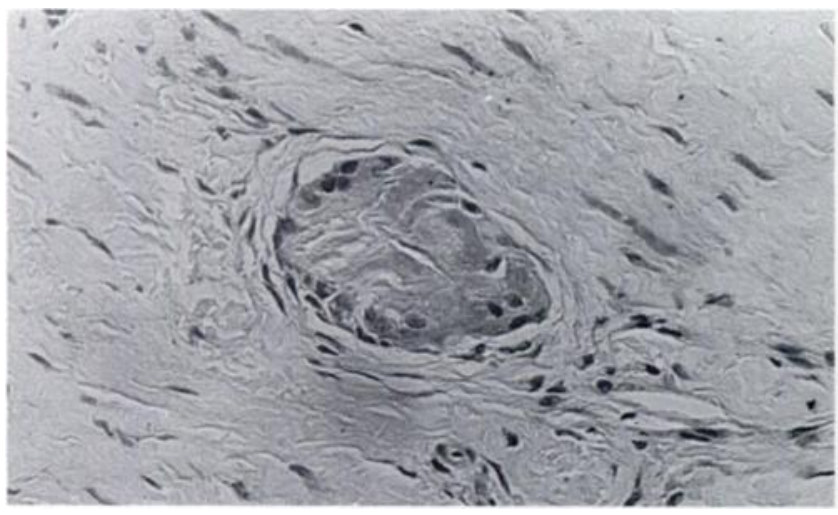

Fig. 3a

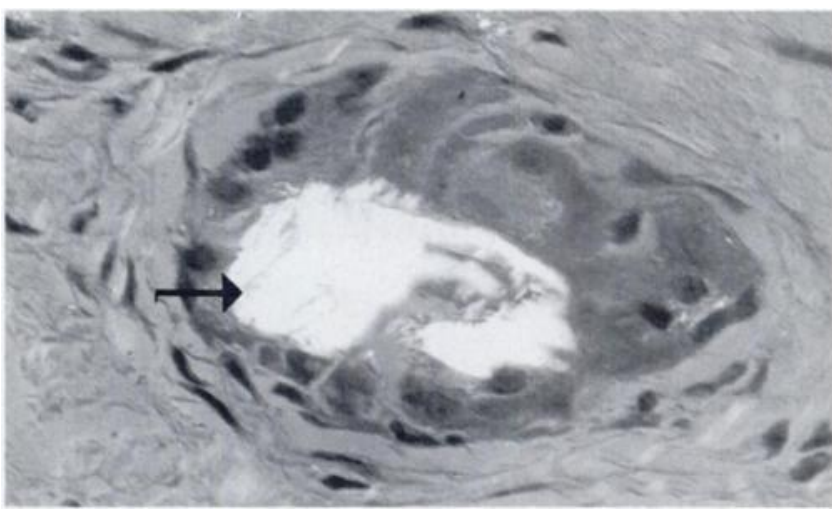

Fig. 3b

Case 23. Arachnoid tissue biopsy showing a multi-nucleate giant cell containing fragments of birefringent foreign material. Figure $3 a-$ Transmitted white light (haematoxylin and eosin $x 380$ ). Figure $3 b$ - Polarising microscopy (haematoxylin and eosin $x 500$ ). 
ation of the cellular response and progressive fibrosis, and this is the presumed course of events in the 14 patients we have described. It may be that some persistent fibrillar foreign material is present after all spinal operations but it is not possible to obtain material from patients without the clinical complication. The histological appearances suggest that the foreign material may have a pathogenic role, and it is of interest that a similar macrophage-mediated reaction was caused by an oil-based myelographic medium in two other patients. It is tempting to suggest a similar pathogenesis for periradicular fibrosis after operation and after myelography.

Foreign material was seen in $62 \%$ of our patients. Although it is possible that some other pathogenesis produced progressive fibrosis in the other $38 \%$, it may be that our limited sampling of small biopsies missed some positive material.

It appears likely that the fibrillar foreign material was introduced by the normal use of swabs and patties during operation, quite possibly carried on the jaws of laminectomy punches and our findings suggest an association with subsequent fibrosis, especially close to delicate structures such as nerve roots. It is implicit that surgical techniques should minimise bleeding, but lavage of the operation site and avoidance of the use of cottonoid patties may help reduce the incidence of
Table II. Staining reactions of cellulose, surgical swabs and patties and the foreign material found in 14 biopsies

\begin{tabular}{|c|c|c|c|}
\hline & Cellulose & $\begin{array}{l}\text { Surgical } \\
\text { swabs and pattie }\end{array}$ & $\begin{array}{l}\text { Foreign } \\
\text { material } \\
\text { from biopsies }\end{array}$ \\
\hline $\begin{array}{l}\text { Physical } \\
\quad \text { Polarising } \\
\quad \text { microscopy }\end{array}$ & birefringent & birefringent & birefringent \\
\hline $\begin{array}{l}\text { Histochemical } \\
\text { PAS } \\
\text { Congo red } \\
\text { Grocotts Gomori } \\
\text { Schweizer's } \\
\text { reagent } \\
\text { Iodine-sulphuric } \\
\text { acid }\end{array}$ & $\begin{array}{l}+++ \\
+++ \\
+++ \\
\text { dissolves } \\
\text { brown to blue }\end{array}$ & $\begin{array}{l}+ \\
+ \\
++ \\
\text { dissolves } \\
\text { brown to blue }\end{array}$ & $\begin{array}{l}+ \\
+ \\
++ \\
\text { dissolves } \\
\text { brown to blue }\end{array}$ \\
\hline $\begin{array}{l}\text { Enzymatic } \\
\text { Cellulose }\end{array}$ & +++ & +++ & +++ \\
\hline
\end{tabular}

fibrosis (Thomas, Ashfar and Roper 1985). Further research is indicated into the nature and design of surgical swabs and patties; the aims should be to minimise fragmentation and shedding of debris, and to reduce the fibrogenic properties of this material.

We would like to thank Miss B. Lomas of the Textile Technology Department, the University of Manchester Institute of Science and Technology for identifying the cotton fibres in the swabs and patties. No benefits in any form have been received or will be received from a commercial party related directly or indirectly to the subject of this article.

\section{REFERENCES}

Benoist M, Ficat C, Baraf P, Cauchoix J. Postoperative lumbar epiduro-arachnoiditis: diagnosis and therapeutic aspects. Spine $1980 ; 5: 432-6$.

Burton CV. The etiology of the "failed back surgery syndrome". In: Canthen JC, ed. Lumbar spine surgery: indications, techniques, failures and alternatives. Baltimore, etc: Williams and Wilkins, 1983:190-203.

Cark K. Significance of the small lumbar spinal canal: cauda equina compression syndromes due to spondylosis. 2. Clinical and surgical significance. J Neurosurg 1969;31:495-98.

Deporter DA. The role of the macrophage in collagen resorption during chronic inflammation: a new look at an old hypothesis. Agents Actions 1979;9:168-71.

Freilick D, Swash M. Diagnosis and management of tuberculosis paraplegia with special reference to tuberculosis radiculomyelitis. J Neurol Neurosurg Psychiatry. 1979;42:12-8.

Gatenby JB, Beams HW, eds. The microtomist's vade-mecum (Bolles Lee): a handbook of the methods of animal and plant microscopic technique. IIth ed. London: J \& A. Churchill Ltd, 1950.

Jakobsen JK. Clinical evaluations of a histologic examination of the side effects of myelographic contrast media. Acta Radiol [Diag] (Stockh) 1973;14:638-46.
Ransford AO, Harries BJ. Localised arachnoiditis complicating lumbar disc lesions. J Bone Joint Surg [Br] 1972;54-B:656-65.

Reisner LS, Hochman BN, Plumer MH. Persistent neurologic deficit and adhesive arachnoiditis following intrathecal 2-chloroprocaine injection. Anaesth Analg 1980;59:452-4.

Seaton A. Asbestosis. In: Morgan WKG, Seaton A, eds. Occupational lung diseases. Philadelphia, etc: WB Saunders, 1975:124-48.

Thomas AMC, Ashfar F, Roper BA. Microfenestration of lumbar intervertebral disc. J Bone Joint Surg [Br] 1985;67-B:151.

Van Akkeveeken PF, Van De Kraan W, Muller JW. The fate of the free fat graft: a prospective clinical study using CT scanning. Spine $1986 ; 11: 501-4$.

Wahl SM. Lymphocyte and macrophage derived growth factors. In: Myelofibrosis and the biology of connective tissue. AR Liss Inc., New York, 1984;143-154.

Werb Z, Bainton DF, Jones PA. Degradation of connective tissue matrices by macrophages. III. Morphological and biochemical studies on extracellular, pericellular and intracellular events in matrix proteolysis by macrophages in culture. J Exp Med 1980;152:1537-53. 